\title{
Toxicity of four kind plant extracts (Ageratum conyzoides L., Barringtonia asiatica (L.) Kurz., Melia azedarach L., Tephrosia vogelii Hook F.) against brown planthopper (Nilaparvata lugens STAL.)
}

\author{
Giannisa Febritami ${ }^{1}$, N Usiati ${ }^{2}$, Danar Dono ${ }^{3 *}$ \\ ${ }^{1}$ Graduate of Department of Plant Pests and Diseases, Agriculture Faculty, Universitas Padjadjaran, Jatinangor, West Java, \\ Indonesia, 45363 \\ ${ }^{2}$ Center for Rice Research Institute, Subang, West Java, Indonesia, \\ ${ }^{3}$ Departement of Chemistry, Faculty of Mathematic and Natural Sciences, Universitas Padjadjaran, Jatinangor, \\ West Java, Indonesia, 45363. \\ *Corresponding Author: danar.dono@unpad.ac.id
}

\begin{abstract}
One of the main pests that attack rice plants is the brown planthopper (BPH), Nilaparvata lugens. Awareness of the negative effects of synthetic insecticides that have been used to control BPH has encouraged the use of natural resources for crop protection. The plant is one of natural source that can be used in the crop protection. Some plant species that have been known to have insecticidal activities include Ageratum conyzoides (Asteraceae), Barringtonia asiatica (Lechytidaceae), Melia azedarach (Meliaceae) and Tephrosia vogelii (Fabaceae). In this study toxicity test of the plant extracts was carried out on BPH, and its phytotoxicity was observed in rice plants. In the toxicity test of the plant extracts against $N$. lugens and the phytotoxicity test on rice plants used 2 concentrations namely $0.1 \%$ and $0.5 \%$ from each plant extract, while the antioviposition test used a concentration of $0.5 \%$. The results showed that the methanolic extract of T. vogelii with a concentration of $0.5 \%$ caused the highest mortality of brown plant hopper nymphs of $42.5 \%$ and at concentration of $0.5 \%$ the four plant extracts did not inhibit oviposition activity of $N$. lugens female and did not phytotoxic on rice plants.
\end{abstract}

Keywords: Toxicity, anti oviposition, plant extract, brown planthopper

\section{ABSTRAK}

Toksisitas Empat Jenis Ekstrak Tumbuhan (Ageratum conyzoides L., Barringtonia asiatica (L.) Kurz., Melia azedarach L., Tephrosia vogelii HOOK F.) Terhadap Wereng Batang Coklat (Nilaparvata lugens Stal.)

Salah satu hama utama yang menyerang tanaman padi adalah wereng batang coklat (WBC), Nilaparvata lugens. Kesadaran akan dampak negatif insektisida sintetik yang selama ini digunakan untuk mengendalikan WBC mendorong penggunaan bahan-bahan alam untuk perlindungan tanaman. Salah satu sumber bahan alami yang dapat digunakan dalam perlindungan tanaman yaitu tumbuhan sebagai bahan insektisida nabati. Beberapa jenis tumbuhan yang telah diketahui memiliki aktivitas insektisida antara lain Ageratum conyzoides (Asteraceae), Barringtonia asiatica (Lechytidaceae), Melia azedarach (Meliaceae) dan Tephrosia vogelii (Fabaceae). Pada penelitian ini dilakukan pengujian toksisitas ekstrak tumbuhan tersebut terhadap WBC, serta diamati fitotoksisitasnya pada tanaman padi. Pada uji toksisitas ekstrak tumbuhan tersebut terhadap serangga dan uji fitotoksisitas pada tanaman padi digunakan 2 konsentrasi yaitu $0,1 \%$ dan $0,5 \%$ dari masing-masing ekstrak tumbuhan, sedangkan pada pengujian anti-oviposisi digunakan konsentrasi $0,5 \%$. Hasil penelitian menunjukkan bahwa ekstrak metanol T. vogelii dengan konsentrasi $0,5 \%$ menyebabkan mortalitas nimfa wereng coklat tertinggi yaitu sebesar 42,5\% dan pada konsentrasi 0,5\% keempat ekstrak tumbuhan tidak menghambat aktivitas oviposisi dari imago betina WBC dan tidak menyebabkan fitotoksisitas pada tanaman padi.

Katakunci: Toksisitas, ekstrak tumbuhan, wereng coklat

\section{PENDAHULUAN}

Petani di Indonesia pada umumnya menggunakan insektisida sintetik untuk melindungi tanaman budidaya. Dampak negatif penggunaan insektisida sintetik yang tidak bijaksana dapat menyebabkan pencemaran lingkungan, beracun terhadap organisme bukan sasaran, dan berpengaruh bagi kesehatan manusia. Hal tersebut berdampak pada bangkitnya minat "back to nature" untuk menggunakan bahan-bahan alami dalam perlindungan tanaman (Dadang 1999; Deepa et al., 2011).

Sumber bahan alami yang dapat digunakan dalam perlindungan tanaman dapat berasal dari tumbuhan dan berfungsi sebagai bahan insektisida nabati. Tumbuhan memiliki berbagai senyawa kimia diantaranya metabolit sekunder yang digunakan oleh tumbuhan sebagai alat pertahanan diri dari serangan organisme pengganggu (Kardinan, 2011). Kandungan metabolit sekunder dalam tumbuhan memiliki beragam pengaaruh terhadap serangga, misalnya menyebabkan gangguan pertumbuhan dan perkembangan, penolak oviposisi, pengurangan kesuburan selain mengakibatkan kematian bagi serangga (Showket et al., 2014).

Beberapa jenis tumbuhan yang telah diketahui memiliki aktivitas insektisida nabati antara lain Ageratum conyzoides (Asteraceae), Barringtonia asiatica (Lechytidaceae), Melia azedarach 
(Meliaceae) dan Tephrosia vogelii (Fabaceae). Tumbuhan famili Asteraceae yaitu A. conyzoides yang banyak tumbuh sebagai gulma memiliki aktivitas insektisida nabati terhadap larva Spodoptera litura (Lumowa, 2011). Tumbuhan B. asiatica yang termasuk ke dalam famili Lechytidaceae memiliki aktivitas toksik terhadap serangga hama ordo Lepidoptera seperti Crocidolomia pavonana dan Spodoptera litura (Dono \& Sudjana, 2007; Arisanti \& Dono, 2012). Tumbuhan mindi atau Melia azedarach termasuk kedalam famili meliaceae. Umumnya famili meliaceae dapat mengendalikan hama dengan alat mulut menggigit mengunyah, tetapi juga memiliki sifat antifeedant dan repellent yang dapat mencegah hama-hama lain untuk makan dan bertelur pada tanaman (Dadang, 1999). Tumbuhan famili fabaceae yaitu kacang babi atau $T$. vogelii dapat digunakan untuk mengendalikan hama dengan menghaluskan dan mencampurnya dengan air atau pelarut lain (Kardinan, 2005). Di daerah Pangalengan, petani sayuran banyak memanfaatkan perasan $T$. vogelii untuk mengendalikan hama penggorok daun kentang Liriomyza sp. dan ulat grayak Spodoptera litura (Prijono, 1999a).

Salah satu OPT utama yang menyerang tanaman padi adalah wereng batang coklat (WBC) atau Nilaparvata lugens Stål. WBC dapat menyerang langsung tanaman padi dengan cara menghisap cairan sel tanaman sehingga tanaman padi menjadi kering (Nurbaeti dkk., 2010). Secara tidak langsung serangan WBC juga dapat mentransfer virus yang berbahaya bagi tanaman padi, yaitu virus kerdil hampa, virus kerdil rumput tipe 1 dan tipe 2 (Baehaki, 2012). Kemunculan dan letusan hama WBC di Indonesia terjadi karena pemakaian insektisida kimia sintesik yang berlebihan sehingga menimbulkan resurgensi pada WBC. Pada tahun 1978-1979 terjadi letusan hama WBC meliputi ratusan ribu sawah padi di Indonesia yang mengakibatkan pencapaian sasaran produksi beras nasional terhambat (Untung, 2006).

A. conyzoides, B. asiatica, M. azedarach dan T. vogelii diketahui memiliki aktivitas biologi terhadap beberapa serangga hama pertanian. Berdasarkan penelusuran literatur, ekstrak-ekstrak tersebut sudah sering digunakan untuk mengendalikan hama-hama pertanian pada tanaman hortikultura, sedangkan untuk pengendalian terhadap hama tanaman pangan khususnya WBC masih jarang dilaporkan. Oleh karena itu, perlu dilakukan penelitian mengenai toksisitas ekstrak A. conyzoides, $B$. asiatica, $M$. azedarach dan $T$. vogelii terhadap WBC, serta fitotoksisitasnya pada tanaman padi.

\section{BAHAN DAN METODE}

Pembuatan ekstrak metanol daun A conyzoides, biji B. Asiatica, M. azedarach dan daun $T$. vogelii dilakukan di Laboratorium Pestisida dan Toksikologi Lingkungan Departemen Hama dan Penyakit Tumbuhan, Fakultas Pertanian, Universitas Padjadjaran, Jatinangor. Percobaan dilakukan di
Laboratorium dan Rumah Kasa Kelompok Peneliti Proteksi, Balai Besar Penelitian Tanaman Padi (BBPTP), Sukamandi- Subang.

\section{Persiapan Percobaan}

Persiapan percobaan yang dilakukan meliputi pembuatan ekstrak, penanaman padi, pemeliharaan serangga uji dan pemisahan nimfa wereng coklat sebelum perlakuan.

\section{Pembuatan Ekstrak}

Tumbuhan sumber ekstrak daun A.conyzoides dan daun $T$. vogelii diperoleh dari Kebun Percobaan Fakultas Pertanian, Universitas Padjadjaran, Unit Ciparanje, Jatinangor. Adapun biji B. asiatica dan biji $M$. azedarach diperoleh dari kampus Departemen Hama dan Penyakit Tumbuhan, Fakultas Pertanian, Universitas Padjadjaran, Jatinangor.

Bagian tumbuhan yang digunakan dari tumbuhan A. conyzoides dan T.vogelii adalah daun, pada tumbuhan $B$. asiatica dan $M$. azedarach bagian tanaman yang digunakan adalah biji. Pada $M$. azedarach, biji dipisahkan dari kulit buahnya, sedangkan biji buah $B$. asiatica diiris tipis-tipis terlebih dahulu, bahan-bahan daun dan biji tersebut kemudian dikeringanginkan, setelah kering dihaluskan dengan mesin giling hingga berbentuk serbuk. Masing-masing serbuk ini kemudian direndam di dalam metanol, dengan perbandingan serbuk dan metanol 1:10 (w/v) selama 3 x 24 jam, selanjutnya disaring menggunakan kertas saring. Hasil penyaringan kemudian diuapkan menggunakan rotary evaporator pada suhu $55-60{ }^{\circ} \mathrm{C}$ dan penghampaan pada tekanan 580-600 $\mathrm{mmHg}$ sehingga diperoleh ekstrak pekat A. conyzoides, B.asiatica, M. azadirach, dan T. vogelii. Ekstrak yang dihasilkan dari rangkaian prosedur kerja di atas, di tempatkan dalam wadah kaca dan simpan dalam lemari es pada suhu $\pm 4^{\circ} \mathrm{C}$. Ekstrak dikeluarkan pada saat akan dilakukan pengujian.

\section{Penanaman Padi}

Padi yang digunakan adalah varietas IR64 yang didapat dari Unit Pengembangan Benih Sumber (UPBS), Balai Besar Penelitian Tanaman Padi BBPTP Sukamandi - Subang. Penanaman padi dilakukan secara bertahap untuk keperluan penyediaan pakan dan perlakuan serangga uji. Benih padi direndam dengan air dengan volume air 2 kali volume benih selama 24 jam untuk memisahkan benih yang bernas dan benih yang hampa. Benih padi yang bernas kemudian di semai pada baki yang berukuran $30 \mathrm{~cm}$ x $35 \mathrm{~cm}$ yang berisi media tanam tanah lembang dan pupuk kompos perbandingan 1:1, kemudian diberi air sampai tanah basah. Saat persemaian pupuk majemuk NPK Phonska diberikan dengan dosis 2 gram dalam 1 baki persemaian, penyiraman dilakukan setiap hari, setelah tanaman padi berumur 4 minggu tanaman padi siap untuk perlakuan. 


\section{Perbanyakan Massal Wereng Batang Coklat}

Serangga uji yang digunakan adalah WBC populasi lapang koloni Indramayu yang diperoleh dari Balai Besar Penelitian Tanaman Padi (BBPTP), Sukamandi- Subang. WBC diperbanyak pada padi varietas IR64 yang berumur 30-45 HST (hari setelah tanam). Disebut sebagai koloni Indramayu karena wereng coklat tersebut diperoleh dari daerah Indramayu. Tidak dilakukan uji biotipe pada serangga uji WBC ini, sehingga tidak diketahui dan dikelompokkan ke dalam suatu biotipe.

Padi IR64 yang berumur 30-45 HST dari lapangan dibersihkan dari kotoran dan pelepah daun tua. Padi ditanam dalam ember-ember plastik berdiameter $27 \mathrm{~cm}$ dan tingginya $20 \mathrm{~cm}$. Emberember tersebut diisi dengan tanah sawah yang dilumpurkan. Tanah sawah yang digunakan bebas dari residu insektisida. Tanaman padi pada ember diberi kurungan plastik mika berbentuk silinder berdiameter $20 \mathrm{~cm}$ dan tingginya $100 \mathrm{~cm}$ yang diberi dua jendela, jendela atas dan jendela bawah yang sudah diberi penutup kain kasa untuk sirkuasi udara, kemudian diinfestasi 20 ekor WBC betina yang telah bunting pada kurungan dibiarkan selama 24 jam. Setelah 24 jam WBC betina tersebut dikeluarkan dan dipindahkan ke dalam kurungan lain. Hal ini berujuan agar diperoleh telur-telur yang berumur sama sehingga nantinya nimfa yang akan digunakan umurnya seragam. Perbanyakan diulang tiga kali, dipelihara dan disimpan dalam rumah kasa.

\section{Pemisahan Nimfa Wereng Batang Coklat sebelum Aplikasi Uji Mortalitas}

Sehari sebelum aplikasi, nimfa WBC dipisahkan terlebih dahulu dari tanaman padi pemeliharaan WBC ke tabung reaksi masing-masing sebanyak 10 ekor pertabung menggunakan aspirator (Gambar 1A). Tabung reaksi tersebut telah berisi satu tanaman padi berumur 4 minggu sebagai pakan yang pada bagian akarnya dibalut dengan tisu kemudian dimasukkan ke dasar tabung reaksi yang telah berisi sedikit air, setelah dimasukkan nimfa WBC, tabung reaksi ditutup menggunakan kain kasa dan diikat karet gelang (Gambar 1B). Pemisahan ini bertujuan, agar pada saat aplikasi nimfa yang telah dipisahkan tersebut dapat langsung diinfenstasikan ke setiap gelas unit perlakuan sehingga dapat menghemat waktu.
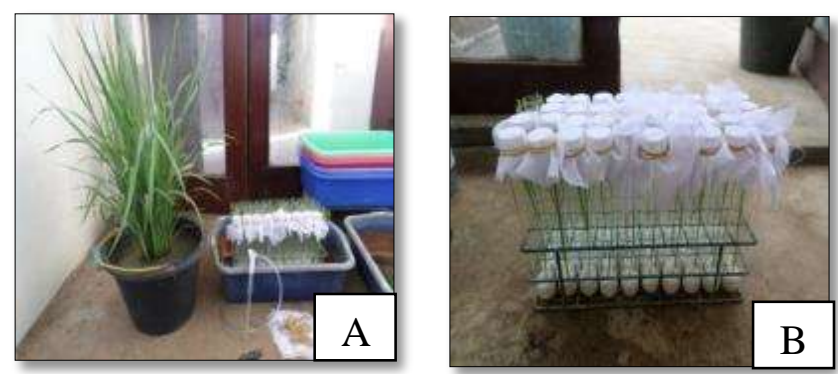

Gambar 1. Pemisahan Nimfa dari Tanaman ke Tabung Reaksi (A), Tabung Reaksi yang Telah Berisi Nimfa ditutup dengan Kain Kasa (B)

\section{Pelaksanaan Percobaan}

Pelaksanaan percobaan meliputi uji mortalitas empat ekstrak tumbuhan terhadap nimfa instar III WBC, uji antioviposisi ekstrak terhadap imago betina WBC dan fitotoksisitas pada tanaman padi.

\section{Uji Mortalitas Empat Ekstrak Tumbuhan terhadap Wereng Batang Coklat}

Percobaan dilakukan untuk mengetahui toksisitas ekstrak metanol empat jenis ekstrak tumbuhan yaitu A. conyzoides, B. asiatica, $M$. azedarach dan $T$. vogelii terhadap mortalitas nimfa instar III WBC. Pengujian dilakukan dengan metode aplikasi semprot tanaman. Rancangan yang digunakan adalah Rancangan Acak Lengkap (RAL). Percobaan tersusun atas 9 perlakuan dan diulang 4 kali sehingga terdapat 36 unit perlakuan. perlakuan terdiri dari Ageratum conyzoides konsentrasi $0,1 \%$ dan $0,5 \%$, Barringtonia asiatica konsentrasi $0,1 \%$ dan $0,5 \%$, Melia azedarach konsentrasi $0,1 \%$ dan $0,5 \%$, Tephrosia vogelii konsentrasi $0,1 \%$ dan $0,5 \%$, dan kontrol.
Setiap unit perlakuan terdapat satu tanaman padi berumur 4 minggu yang disiapkan dalam gelas plastik yang berisi tanah lembang sebagai media tanam. Larutan ekstrak metanol dari A. conyzoides, $B$. asiatica, $M$. azedarach dan $T$. vogelii sebanyak $4 \mathrm{ml}$ disemprotkan pada tanaman padi uji secara merata pada seluruh bagian tanaman dengan konsentrasi sesuai perlakuan menggunakan hand sprayer, setelah itu, dikurung dengan gelas plastik seukuran yang dipasang terbalik dengan bagian atas telah dipotong dan diberi kain kasa. Selanjutnya dalam setiap unit perlakuan diinfenstasi 10 ekor nimfa WBC instar III. Setiap larutan uji $0,1 \%$ dan $0,5 \%$ dibuat dengan mencampur ekstrak metanol empat tumbuhan tersebut sebanyak $0,1 \mathrm{~g}$ dan $0,5 \mathrm{~g}$ dalam campuran metanol 2 $\mathrm{ml}$, agristik $0.5 \mathrm{ml} / \mathrm{L}$ dan akuades sampai volume 100 $\mathrm{ml}$.

Pengamatan dilakukan terhadap mortalitas nimfa WBC sejak hari pertama aplikasi dimulai dari nimfa instar III sampai WBC menjadi imago. Kriteria nimfa yang mati yaitu apabila disentuh dengan kuas, nimfa tidak bergerak. Cara menghitung mortalitas nimfa menggunakan rumus: 


$$
\text { Mortalitas (\%) }=\frac{\text { Jumlah WBC mati }}{\text { Jumlah WBC uji }} \times 100 \%
$$

Apabila pada kontrol mortalitas nimfa kurang dari 20\%, akan dilakukan koreksi dengan rumus Abbots (Busvine,1971) sebagai berikut:

Keterangan:

$$
\operatorname{Pt}(\%)=\frac{\mathrm{Po}-\mathrm{Pc}}{100-\mathrm{Pc}} \times 100 \%
$$

$\mathrm{Pt}=$ Persentase mortalitas serangga uji yang telah dikoreksi
Po $=$ Persentase mortalitas serangga uji karena perlakuan $\mathrm{Pc}=$ Persentase mortalitas serangga uji pada control

Data yang didapat dianalisis secara statistik menggunakan program SPSS 16.0 dengan Analisis Ragam (Analysis of Variance) dan perbedaan antar perlakuan diuji menggunakan uji jarak berganda Duncan pada taraf nyata 5\%. Aktifitas ekstrak selanjutnya diklasifikasikan berdasarkan kematian nimfa (Tabel 1) menurut Syahputra \& Endarto (2013).

Tabel 1. Aktivitas Ekstrak Berdasarkan Kematian Nimfa

\begin{tabular}{ll}
\hline Aktivitas ekstrak & Selang \\
\hline Sangat kuat & Mortalitas $(\mathrm{m})=100 \%$ \\
Kuat & $85 \%<\mathrm{m}<99 \%$ \\
Cukup kuat & $60 \%<\mathrm{m}<85 \%$ \\
Agak lemah & $\mathrm{m}<60 \%$ \\
\hline
\end{tabular}

Uji Pengaruh Antioviposisi Keempat Ekstrak Tumbuhan terhadap Imago Betina WBC

Percobaan dilakukan untuk menguji pengaruh antioviposisi ekstrak metanol empat tumbuhan yaitu $A$. conyzoides, B. asiatica, $M$. azedarach dan $T$. vogelii terhadap aktivitas oviposisi WBC. Setiap ekstrak yang diuji dilarutkan dalam campuran metanol $2 \mathrm{ml}$, agristik $0.5 \mathrm{ml} / \mathrm{L}$ dan akuades sampai volume $100 \mathrm{ml}$. Percobaan disusun menggunakan Rancangan Acak Lengkap dengan lima perlakuan dan lima ulangan. Perlakuan terdiri dari empat ekstrak tumbuhan uji konsentrasi $0.5 \%$ dan kontrol. Setiap 24 jam sekali, imago WBC betina yang bunting dipindahkan ke tanaman padi baru selama 4 hari, sehingga terdapat 100 unit gelas yang berisi satu tanaman padi. Setiap unit diinfenstasikan dua imago betina WBC yang telah bunting.

Metode pengujian dilakukan dengan metode penyemprotan tanaman. Satu tanaman padi yang berumur 4 minggu yang telah disiapkan dalam gelas plastik dengan media tanam tanah lembang disemprot dengan masing-masing larutan ekstrak secara merata pada seluruh bagian tanaman sebanyak $4 \mathrm{ml}$ menggunakan hand sprayer. Dua imago betina WBC yang telah bunting diinfenstasi kedalam tanaman padi yang telah diberi perlakuan.

Pengamatan dilakukan dengan menghitung jumlah telur yang diletakkan imago WBC dengan membedah tanaman padi dan diamati di bawah stereo mikroskop. Setiap data perlakuan diolah statistik dengan analisis ragam (Analysis of Variance) dengan program SPSS 16.0 dan bila ada perbedaan antar perlakuan di uji menggunakan uji jarak berganda Duncan pada taraf nyata $5 \%$.

\section{Uji Fitotoksisitas Empat Ekstrak Tumbuhan terhadap Tanaman Padi}

Pada uji fitotoksisitas, konsentrasi yang digunakan sama dengan perlakuan uji mortalitas. Setiap ekstrak yang diuji dilarutkan dalam campuran metanol $2 \mathrm{ml}$, agristik $0.5 \mathrm{ml} / \mathrm{L}$ dan akuades sampai volume $100 \mathrm{ml}$ Percobaan disusun atas sembilan perlakuan dan diulang sebanyak empat kali.

Aplikasi dilakukan pada tanaman padi yang berumur 4 minggu yang disemprot dengan masingmasing ekstrak tumbuhan sebanyak $4 \mathrm{ml}$. Pengamatan dilakukan setiap hari setelah aplikasi selama enam hari dengan mengamati gejala fitotoksisitas dengan mengamati bagian helai daun tanaman yang mengalami nekrosis atau pengerutan menggunakan kertas milimeter blok dengan rumus menurut Syahputra, (2010).

\section{HASIL DAN PEMBAHASAN \\ Mortalitas Wereng Batang Coklat}

Berdasarkan hasil pengujian, diperoleh satu ekstrak yang memiliki nilai mortalitas lebih tinggi dibandingkan dengan ekstrak tumbuhan lainnya, yaitu ekstrak metanol $T$. vogelii konsentrasi $0,5 \%$. Ekstrak metanol $T$. vogelii mengakibatkan mortalitas sebesar $42,50 \%$ nimfa WBC pada delapan hari setelah perlakuan, sedangkan ekstrak tumbuhan lainnya tidak berbeda nyata antar perlakuan atau tidak memberikan pengaruh terhadap mortalitas nimfa WBC (Tabel 2).

Meskipun ekstrak metanol T. vogelii mengkibatkan mortalitas yang paling tinggi diantara ekstrak tumbuhan lainnya, namun menurut pengklasifikasian aktivitas ekstrak berdasarkan kematian nimfa oleh Syahputra \& Endarto (2013), ekstrak T. vogelii $0,5 \%$ yang mengakibatkan kematian nimfa WBC sebesar 42,50\% tergolong agak lemah. Ekstrak dikatakan efektif apabila ekstrak yang diuji pada konsentrasi awal tidak melebihi $0,5 \%(0,5 \mathrm{~g} / 100$ $\mathrm{ml}$ ) dapat mengakibatkan kematian $\geq 90 \%$ (Prijono, 1999b).

Mortalitas nimfa pada perlakuan ekstrak metanol T. vogelii dengan konsentrasi $0,5 \%$ telah terjadi pada hari pertama dan mengalami peningkatan pada hari ketiga dan keempat setelah perlakuan, sedangkan hingga pengamatan kedelapan tidak ada peningkatan atau pengurangan mortalitas (stagnansi). Hali ini, menunjukkan berkurangnya efek dari ekstrak metanol T. vogelii terhadap nimfa WBC. Kematian nimfa WBC 
oleh perlakuan $T$. vogelii $0,5 \%$ disebabkan oleh senyawa aktif rotenon yang terkandung dalam ekstrak metanol daun $T$. vogelii bersifat sebagai insektisida. Menurut Gaskins et al., (1972), T. vogelii mengandung senyawa rotenoid yang bersifat insektisida seperti rotenon, tephrosin, deguelin dan 6a, 12a-dehydrodeguelin dengan kandungan rotenon dan deguelin yang lebih dominan dari senyawa lainnya. Rotenon merupakan senyawa insektisida dalam T. vogelii yang paling aktif (Matsumura, 1985). Diduga senyawa rotenon masuk kedalam tubuh nimfa dengan cara kontak ketika nimfa tersebut diinfestasikan pada tanaman padi yang basah setelah disemprot larutan ekstrak daun $T$. vogelii masuk ke dalam pencernaan nimfa sehingga mengalami keracunan dan akhirnya mati. Hal ini sejalan dengan penelitian lainnya bahwa kandungan senyawa rotenon dalam daun $T$. vogelii dapat menyebabkan kematian pada serangga.

Syahroni \& Prijono, (2013) melaporkan bahwa ekstrak metanol daun kacang babi atau $T$. vogelii menyebabkan kematian pada larva C. pavonana. Menurut Kardinan (2005) rotenon merupakan racun perut dan kontak. Pada tingkat sel, rotenon bekerja sebagai racun respirasi yang secara spesifik menghambat aktivitas transfer elektron dari kompleks I melalui penghambatan enzim Nikotinamida Adenosin Dinukleotida Hidrogen (NADH) ke ubiquinone selama fosforilasi oksidatif pada sebagian besar sel, sehingga menggangu rantai transport elektron dalam mitokondria. Hambatan ini mencegah kofaktor NADH untuk memproses energi dalam bentuk adenosine triphosphatase (ATP) (Singer and Ramsay, 1994; Heong et al., 2013).

Dilihat dari pengamatan langsung, nimfa yang mati akibat perlakuan ekstrak daun $T$. vogelii sebagian berwarna kehitaman (Gambar 2A) dan sebagian mengalami kematian pada saat menjelang atau pada saat ganti kulit (Gambar 2B). Nimfa tidak dapat melepaskan diri dari kutikutila lama secara sempurna pada saat pergantian kulit sehingga akhirnya mati (Gambar 2B).

Tabel 2. Persentase Mortalitas Nimfa Wereng Batang Coklat pada 8 Hari Setelah Perlakuan

\begin{tabular}{lcl}
\hline Perlakuan & Konsentrasi (\%) & \% Mortalitas \pm SD \\
\hline A. conyzoides & 0,1 & $2,50 \pm 5,00 \mathrm{a}$ \\
& 0,5 & $5,00 \pm 5,77 \mathrm{a}$ \\
B. asiatica & 0,1 & $7,50 \pm 15,00 \mathrm{a}$ \\
& 0,5 & $2,50 \pm 5,00 \mathrm{a}$ \\
M. azedarach & 0,1 & $2,50 \pm 5,00 \mathrm{a}$ \\
& 0,5 & $2,50 \pm 5,00 \mathrm{a}$ \\
T. vogelii & 0,1 & $2,50 \pm 5,00 \mathrm{a}$ \\
Kontrol & 0,5 & $42,50 \pm 29,86 \mathrm{~b}$ \\
\hline
\end{tabular}

Keterangan : Angka rata-rata mortalitas pada tiap kolom yang diikuti huruf yang sama menunjukkan tidak berbeda nyata menurut Uji Jarak Berganda Duncan taraf 5\% SD : Standar deviasi

Serangga mengalami pergantian kulit dalam rangka pertumbuhan dan perkembangannya. Kutikula tidak akan terus berkembang karena akan mengeras melalui proses sklerotisasi dan dapat membatasi pertumbuhan serangga, sehingga serangga perlu untuk melepaskan kulit luarnya (kutikula) secara berkala agar dapat tumbuh dan berkembang (Champman, 2013). Pada penelitian mungkin saat pergantian kulit, nimfa WBC mengalami kematian sehingga nimfa tidak dapat melanjutkan hidup pada perkembangan instar selanjutnya.

Ekstrak metanol A. conyzoides, B.asiatica dan $M$. azedarach pada konsentrasi $0,1 \%$ dan $0,5 \%$

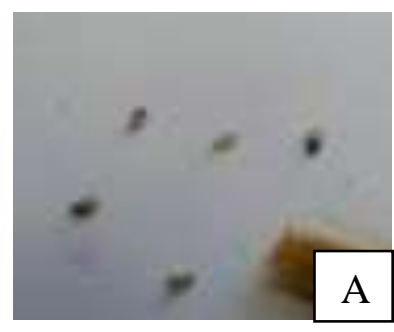

menyebabkan tingkat mortalitas nimfa berkisar antara $2,50 \%$ sampai dengan $7,50 \%$. Rendahnya mortalitas nimfa WBC oleh ketiga ekstrak tumbuhan tersebut diduga karena kandungan ketiga ekstrak tumbuhan tersebut tidak cukup untuk mematikan nimfa WBC. Bila dikaitkan dengan perilaku makan nimfa wereng coklat yang menghisap cairan tanaman padi, kemungkinan ekstrak metanol tumbuhan tersebut tidak bersifat sistemik pada tanaman padi dan hanya menempel di permukaan tanaman padi saja, sehingga racun yang masuk ke tubuh nimfa sedikit dan mortalitas nimfa sangat rendah dan dikatakan tidak aktif.

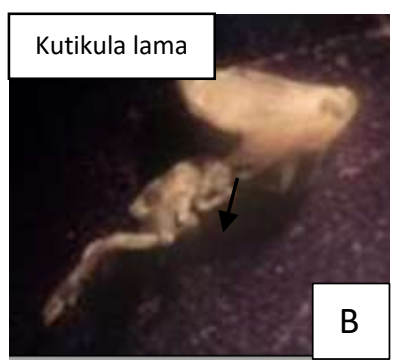

Gambar 2. Nimfa WBC yang Mati pada Perlakuan T. vogelii 0,5\% (A), WBC yang Mati saat Pergantian Kutikula pada Perlakuan T. vogelii $0,5 \%$ (B) 
Selain mortalitas, dilakukan juga pengamatan terhadap jenis sayap pada imago WBC yaitu jenis brakhiptera (bersayap kerdil) dan jenis makroptera (bersayap panjang) dan pada imago WBC pada perlakuan yang telah diuji (Tabel 3). Dari hasil pengamatan, imago WBC jenis sayap brakhiptera muncul lebih dominan dari pada jenis sayap makroptera pada hampir semua perlakuan dan kontrol. Berbeda dengan perlakuan lainnya, pada perlakuan T.vogelii $0,5 \%$ jenis sayap makroptera yang muncul lebih dominan sebanyak $73,91 \%$ sedangkan jenis sayap brakhiptera sebanyak 26,08\%. Diduga banyaknya makroptera yang terbentuk setelah perlakuan $T$. vogelii konsentrasi $0,5 \%$ delapan hari setelah perlakuan dikarenakan pengaruh aplikasi $T$. vogelii yang mengandung senyawa insektisida rotenon yang diduga dapat mempengaruhi terhadap respon fisiologis WBC.

Bao et al., (2009), melaporkan aplikasi dosis subletal insektisida imidakloprid dan dinotefuran meningkatkan persentase pembentukan sayap makroptera pada WBC. Selain itu, Zhang et al., (2010) juga melaporkan insektisida nitenphyram berpengaruh pada munculnya imago makroptera yang lebih dominan. Zhang et al., (2010) berpendapat bahwa insektisida dapat mempengaruhi hormon juvenile yang berdampak pada pembentukan sayap. Menurut Ayoade at al., (1996) munculnya imago makroptera mungkin disebabkan oleh insektisida yang bekerja pada sistem endokrin (yang berperan mengendalikan respon fisiologis dan tingkah laku) pada serangga yang mempengaruhi hormon juvenile pada saat serangga mengalami tahapan metamorfosis.

\section{Pengaruh Aktivitas Antioviposisi Keempat Ekstrak Tumbuhan terhadap Imago Betina Wereng Batang Coklat}

Hasil percobaan menunjukkan bahwa perlakuan ekstrak dari A.conyzoides, B. asiatica, $M$. azedarach, dan T.vogelii pada konsentrasi $0,5 \%$ tidak memberikan pengaruh terhadap antioviposisi pada imago WBC (Tabel 4). WBC melakukan aktivitas oviposisi dengan menusukkan ovipositornya pada pelepah daun dan juga pada tulang daun padi (Gambar 3A) dan meletakkan telurnya secara berderet seperti sesisir buah pisang (Gambar 3B).

Pemilihan tempat bertelur menjadi titik paling kritis dan hal yang penting bagi kebanyakan serangga pemakan tumbuhan (fitofag) untuk kelangsungan hidup keturunannya. Proses penemuan inang tanaman yang baik dan sesuai untuk larva dan nimfa serangga fitofag tergantung pada kemampuan serangga betina dalam menyeleksi senyawa kimia tanaman inang untuk peletakan telurnya (Honda dalam Dadang \& Prijono, 2008). Meskipun tanaman padi sebagai inang WBC untuk meletakkan telur telah disemprot dengan keempat ektrak tumbuhan insektisida nabati, WBC tetap dapat meletakkan telur dalam jaringan tanaman padi. Tidak adanya antioviposisi atau hambatan peletakkan telur oleh imago betina WBC pada tanaman padi yang telah diberi perlakuan ekstrak $A$. conyzoides, B. asiatica, $M$. azedarach dan $T$. vogelii kemungkinan disebabkan oleh konsentrasi yang digunakan tidak cukup untuk menolak aktivitas antioviposisi pada imago WBC.

\section{Uji Fitotoksisitas Empat Ekstrak Tumbuhan pada Tanaman Padi}

Tanaman padi yang disemprot dengan perlakuan ekstrak metanol A. conyzoides, B. asiatica, $M$. azedarach, T.vogelii pada konsentrasi $0,1 \%$ dan $0,5 \%$ selama enam hari pengamatan, tidak menunjukkan gejala fitotoksisitas seperti nekrosis atau pengerutan.

Gejala kerusakan fitotoksik akibat respons tanaman terhadap senyawa kimia biasanya berupa gejala daun terbakar, nekrosis atau pengerutan. Kerusakan dapat terjadi karena matinya sel-sel tanaman yang terkena senyawa kimia dengan toksisitas tinggi (Dadang \& Prijono, 2008). Ekstrak metanol dari A. conyzoides, B. asiatica, M. azedarach dan $T$. vogelii pada konsentrasi $0,1 \%$ dan $0,5 \%$ yang digunakan dalam uji fitotoksisitas ini diduga masih relatif aman pada tanaman padi. Komponen non polar seperti minyak dan cairan pekat yang terkandung pada ekstrak kasar tumbuhan yang digunakan tidak merusak zat lilin pada sel daun sehingga tidak menimbulkan gejala fitotoksisitas. Selain senyawa aktif, senyawa lain yang terkandung dalam larutan semprot seperti metanol $2 \%$ dan agristik $0,5 \mathrm{ml} / 1$ masih relatif aman digunakan. Menurut Dadang \& Prijono (2008), secara umum fitotoksik dapat terjadi karena beberapa faktor seperti kesehatan tanaman, lingkungan fisik seperti sinar matahari, jenis tanaman (berkaitan dengan ketebalan, lekukan daun), bagian tanaman (daun tua, daun muda, pucuk), senyawa kimia atau insektisida yang diaplikasikan (konsentrasi, jenis ekstrak dan bahan tambahan lain seperti pelarut). Faktor lingkungan fisik seperti sinar matahari, suhu dan kelembaban selama percobaan uji fitotoksisitas berlangsung relatif moderate. serta tidak terjadi cekaman cuaca karena percobaan dilakukan di dalam rumah kasa dan telindungi dari hujan. 
Tabel 3. Persentase imago brakhiptera dan makroptera pada delapan hari setelah perlakuan

\begin{tabular}{llll}
\hline Perlakuan & $\mathrm{N}$ & Persentase Brakhiptera & Persentase Makroptera \\
\hline A. conyzoides $0,1 \%$ & 39 & $82,05 \%$ & $17,95 \%$ \\
A. conyzoides $0,5 \%$ & 38 & $60,52 \%$ & $39,48 \%$ \\
B. asiatica $0,1 \%$ & 37 & $67,57 \%$ & $32,43 \%$ \\
B. asiatica $0,5 \%$ & 39 & $69,23 \%$ & $30,77 \%$ \\
M. azedarach $0,1 \%$ & 39 & $84,61 \%$ & $15,39 \%$ \\
M. azedarach $0,5 \%$ & 39 & $64,10 \%$ & $35,80 \%$ \\
T. vogelii $0,1 \%$ & 39 & $61,53 \%$ & $38,47 \%$ \\
T. vogelii $\mathbf{0 , 5 \%}$ & $\mathbf{2 3}$ & $\mathbf{2 6 , 0 8 \%}$ & $\mathbf{7 3 , 9 1 \%}$ \\
Kontrol & 40 & $77,5 \%$ & $22,5 \%$ \\
\hline
\end{tabular}

Tabel 4. Aktivitas antioviposisi keempat ekstrak tumbuhan terhadap imago betina WBC

\begin{tabular}{lllll}
\hline $\begin{array}{l}\text { Perlakuan } \\
(\%)\end{array}$ & \multicolumn{4}{c}{$\begin{array}{c}\text { Rataan jumlah telur yang diletakkan (butir) } \\
(\mathbf{x} \pm \mathbf{S D})^{\mathbf{2} .}\end{array}$} \\
\cline { 2 - 5 } & $\mathbf{1 ~ H S A}$ & $\mathbf{2 ~ H S A}$ & $\mathbf{3 ~ H A S}$ & $\mathbf{4 ~ H A S}$ \\
\hline A. conyzoides 0,5 & $92,00 \pm 25,54$ & $66,60 \pm 22,88$ & $26,60 \pm 37,75$ & $17,20 \pm 22,08$ \\
B. asiatica 0,5 & $98,40 \pm 15,77$ & $65,00 \pm 34,14$ & $82,60 \pm 28,27$ & $13,80 \pm 09,83$ \\
M. azedarach 0,5 & $83,20 \pm 19,44$ & $62,00 \pm 32,69$ & $44,20 \pm 26,67$ & $4,20 \pm 04,91$ \\
T.vogelii 0,5 & $74,00 \pm 25,96$ & $63,00 \pm 43,88$ & $54,60 \pm 25,33$ & $20,40 \pm 14,43$ \\
Kontrol & $94,60 \pm 47,08$ & $80,40 \pm 31,45$ & $59,40 \pm 41,84$ & $16,80 \pm 20,84$ \\
\hline
\end{tabular}

\section{Keterangan:}

1. Perlakuan dengan cara penyemprotan pada tanaman padi, imago betina wereng coklat dipindahkan pada tanaman padi baru setelah 1 hari setelah aplikasi sampai hari ke 4 setelah aplikasi

2. $\mathrm{x}=$ rata-rata jumlah telur yang diletakkan, $\mathrm{SD}=\mathrm{Standar}$ Deviasi

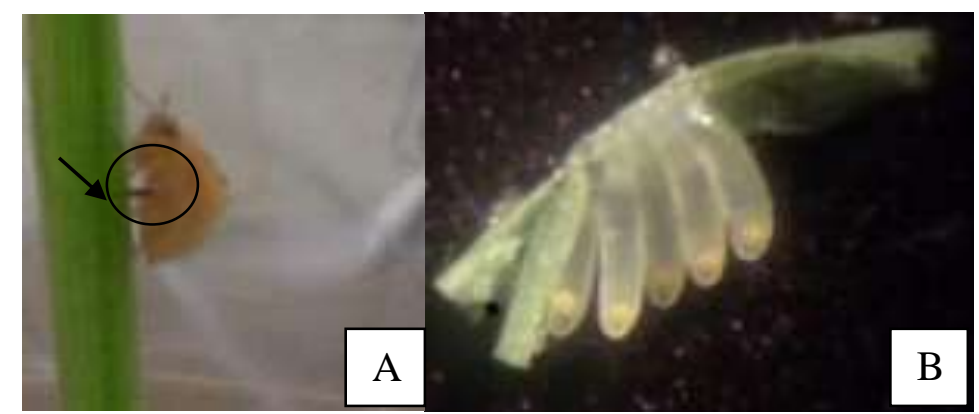

Gambar 3. Oviposisi Imago Betina WBCpada tanaman padi (A), Telur WBC diletakkan secara Berderet (B)

\section{KESIMPULAN}

Diantara keempat ekstrak metanol tumbuhan yang diuji dengan metode semprot tanaman padi, ekstrak metanol $T$. vogelii dengan konsentrasi $0,5 \%$ menyebabkan mortalitas nimfa wereng coklat sebesar 42,5\% paling tinggi dibandingkan dengan ekstrak metanol tumbuhan lainnya. Pada konsentrasi 0,5\% keempat ekstrak tumbuhan tidak menyebabkan penghambatan aktivitas oviposisi pada imago betina wereng coklat dan tidak menyebabkan fitotoksisitas pada tanaman padi.

\section{DAFTAR PUSTAKA}

Ayoade, O., S. Morooka, \& S. Tojo. 1996. Metamorphosis and wing formation in the brown planthopper, Nilaparvata lugens, after topical application of precocene II. Archive of Insect Biochem and Phys. 32: 485-491.

Arisanti, I.M \& D Dono. 2015. Bioaktivitas campuran ekstrak biji Baringtonia asiatica L. (Kurz.) (Lecythicidae) dan Getah Azadirachta indica A. juss (meliaceae) terhadap larva
Spodoptera litura (Lepidoptera:Noctuidae). Jurnal Agrikultura. 26 (1): 30-40.

Baehaki, S.E. 2012. Perkembangan biotipe hama wereng coklat pada tanaman padi. Iptek Tanaman Pangan 7(1): 8-17.

Bao, H., S. Liu, J. Gu, X. Wang, X. Liang \& Z. Liu. 2009. Sublethal effect of four Insecticides on the reproduction and wing formation of brown planthopper, Nilaparvata lugens. Pest. Manag. Sci. 65: 170-174.

Busvine, J.R. 1971. A Critical Review of The Techniques for Testing Insecticides. Commonwealth Agricultural Bureaux. London.

Champman, R.F. 2013. The Insect Structure and Function - Fifth Edition (SJ Simpson and AE Douglas, eds.). Cambridge University Press, New York. Available at http://www.books. google.co.id/books?id=NXJEi8fo7CkC\&PA $463 \&$ Source $=$ gbs_toc_r\&cad $=4 \#$ onepage $\& q$ $\& \mathrm{f}=$ false (diakses April 2014). 
Dadang. 1999. Sumber insektisida alami. Pp. 9-20. Dalam Bahan Pelatihan Pengembangan dan Pemanfaatan Insektisida Alami. Bogor 9-13 Agustus 1999. Pusat Kajian Pengendalian Hama Terpadu. Institut Pertanian Bogor.

Dadang \& D. Prijono. 2008. Insektisida Nabati Prinsip Pemanfaatan dan Pengembangan. Departemen Proteksi Tanaman Fakultas Pertanian, Institut Pertanian Bogor.

Deepa, T.V., G. Lakshmi, P.S. Lakshmi, \& S.K. Sreekanth. 2011. Ecological effect of insecticides. Pp. 327-336. In Pesticides in the Modern World-Pesticides Use Management. (Dr Margarita Atoycheva, eds.). Intech. Available at http://www.intech open.com/books/pesticides-in-the-modernworldpesticides-use-and-management/ ecological-effects-of-pesticide-s (Diakses Mei 2014).

Dono, D. \& N. Sudjana. 2007. Aktivitas insektisida ekstrak daun, kulit, batang dan biji Barringtonia asiatica (Lecythidaceae) terhadap larva Crocidolomia pavonana (Lepidoptera: Pyralidae). Pp. 273-285. Dalam Prosiding Simposium Revitalisasi Penerapan PHT dalam Praktek Pertanian yang Baik Menuju Sistem Pertanian Berkelanjutan. Sukamandi, 10-11 April 2007.

Gaskins, M.H., G.A. White, F.W. Martin, N.E. Delfel, E.G. Ruppel, \& D.K. Barnes. 1972. Tephrosia vogelii: A Source of Rotenoids for Insecticidal and Piscicidal Use. Technical Bulletin No.1445. Agricultural Research Service. United States Departement of Agriculture.

Heong, K.L., K.H. Tan, C.P.F. Garcia, Z. Liu, \& Z. Lu. 2013. Research Methods in Toxocology and Insecticide Resistance Monitoring of Rice Planthoppers, Second edition. International Rice Research. Los Banos (Phillipines). $145 \mathrm{p}$.

Kardinan, A. 2005. Pestisida Nabati Ramuan \& Aplikasi. Penebar Swadaya. Jakarta.

Kardinan. 2011. Pengunaan pestisida nabati sebagai kearifan lokal dalam pengendalian hama tanaman menuju sistem pertanian organik. Pengemb. Inov. Pertanian 4(4): 267-268.

Lumowa. 2011. Efektifitas ekstrak babadotan (Ageratum conyzoides L.) terhadap tingkat kematian larva Spodoptera litura. Eugenia 17(13)- 186-192.
Matsumura, F. 1985. Toxicology of Insecticide. Second ed. Plenum Press. New York.

Nurbaeti, B., I.A. Diratmaja, \& S. Putra. 2010. Wereng Coklat (Nilaparvata lugens Stal.). Balai Pengkajian Teknologi Pertanian Jawa Barat. Balai Penelitian dan Pengembangan Pertanian. Departemen Pertanian.

Prijono, D. 1999a. Pemanfaatan insektisida alami di tingkat petani. Pp 82-86. Dalam Bahan Pelatihan Pengembangan dan Pemanfaatan Insektisida Alami. Bogor 9-13 Agustus 1999. Pusat Kajian Pengendalian Hama Terpadu. Institut Pertanian Bogor.

Prijono, D. 1999b. Prinsip - prinsip uji hayati. Pp. 4562. In Bahan Pelatihan Pengembangan dan Pemanfaatan Insektisida Alami. Bogor 9-13 Agustus 1999. Pusat Kajian Pengendalian Hama Terpadu. Institut Pertanian Bogor.

Showket, A.D., N.A. Dar, M.A. Bhat, \& M.H. Bhat. 2014. Prospect, utilization, and challenges of botanical pesticides in sustainable agriculture. Int. J. Mol. Biol. Biochem. 2(1): $1-14$.

Singer, T.P., \& R.R. Ramsay. 1994. The reaction site of rotenone and ubiquinone with mitochondrial NADH dehydrogenase. Biochim. Biophys. Acta 1187(2): 198-202.

Syahputra, E. 2010. Sediaan insektisida ekstrak biji Mimopus elengi: pengaruh terhadap perkembangan dan keperidian Crocidolomia pavonana serta pengaruh terhadap lingkungan dan tanaman. Bionatura 12(1): 25-30.

Syahputra, E. \& O. Endarto. 2013. Acaricidal activity plant extracts against citrus mites and their effect on predator and citrus plants. J. Agric. Sci. Soil Sci. 3(4): 99-16.

Syahroni YY \& D. Prijono. 2013. Aktivitas insektisida ekstrak buah Piper aduncum L. (Piperaceae) dan Sapindus rarak DC. (Sapindaceae) serta campurannya terhadap larva Crocidolomia pavonana (F.) (Lepidoptera: Crambidae). Jurnal Entomolog Indonesia. 10 (1):39-50.

Untung, K. 2006. Pengantar Pengelolaan Hama Terpadu (Edisi Kedua). Gadjah Mada University Press. Yogyakarta.

Zhang, J., F. Yuan, J. Liu, H. Chen \& R. Zhang. 2010. Sublethal effect on nitenpyram on life - table parameters and wing formation of Nilaparvata lugens (Stål) (Homoptera: Delphacidae). Appl. Entomol. Zool. 45(4): 569-574.

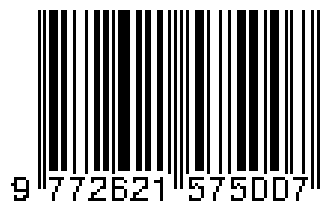

